Research Article

\title{
Is There Deep-Seated Subsidence in the Houston-Galveston Area?
}

\author{
Jiangbo Yu, Guoquan Wang, Timothy J. Kearns, and Linqiang Yang \\ Department of Earth and Atmospheric Sciences, National Center for Airborne LiDAR Mapping, \\ 312 Science \& Research Building 1, Room 312, University of Houston, Houston, TX 77204-5007, USA \\ Correspondence should be addressed to Jiangbo Yu; jyu7@uh.edu
}

Received 3 February 2014; Accepted 4 June 2014; Published 2 July 2014

Academic Editor: Yun-tai Chen

Copyright (C) 2014 Jiangbo Yu et al. This is an open access article distributed under the Creative Commons Attribution License, which permits unrestricted use, distribution, and reproduction in any medium, provided the original work is properly cited.

\begin{abstract}
Long-term continuous groundwater level and land subsidence monitoring in the Houston-Galveston area indicates that, during the past two decades (1993-2012), the groundwater head has been increasing and the overall land subsidence rate has been decreasing. Assuming that the hydraulic head in the aquifer will reach or exceed the preconsolidation level in the near future, will subsidence in the Houston-Galveston area eventually cease? The key to answer this question is to identify if there is deep-seated subsidence in this area. This study investigated the recent subsidence observed at different depths in the Houston-Galveston area. The subsidence was recorded by using 13 borehole extensometers and 76 GPS antennas. Four of the GPS antennas are mounted on the deepanchored inner pipes of borehole extensometers. We conclude that recent subsidence (1993-2012) in the Houston-Galveston area was dominated by the compaction of sediments within $600 \mathrm{~m}$ below the land surface. Depending on the location of specific sites, the compaction occurred within the Chicot aquifer and part or all of the Evangeline aquifer. No measurable compaction was observed within the Jasper aquifer or within deeper strata. Deep-seated subsidence is not likely occurring in the Houston-Galveston area.
\end{abstract}

\section{Introduction}

The Houston-Galveston area provides one of the most extreme case studies of subsidence hazards, which is a problem that affects many other U.S. metropolitan areas, for example, Los Angeles (CA), Sacramento (CA), New Orleans (LA), Phoenix (AZ), and Tucson (AZ) [1-3]. The Houston Ship Channel and the Galveston Bay area have experienced severe subsidence $[4,5]$. Up to four meters of subsidence has occurred in the area along the Houston Ship Channel from 1915-17 to 2001 [5]. The area along the Houston Ship Channel includes Pasadena, Bay Town, Seabrook, and Texas City. Land subsidence has increased the frequency and severity of infrastructure damage and flooding in the Houston-Galveston area. It has been well recognized that recent subsidence in the Houston-Galveston area has occurred as a direct result of ground water withdrawals [6]. Historical subsidence caused by oil and gas production in the Houston-Galveston area was also studied by researchers [7]. Different from ground water, the depth from which the oil and gas are produced would affect the amount of possible subsidence. It is because the deeper the clays are, the more compacted they are and the less they can compact following a reduction in liquid or gas pressure. Holzer and Bluntzer [8] studied subsidence profiles across 29 oil and gas fields in Houston, Texas, from 1943 to 1973. They concluded that the contribution of petroleum withdrawal to local land subsidence is relatively small compared to aquifer compaction. Since 1980s, significant oil and gas production has moved off-shore in the Gulf of Mexico area [9]. Most on-shore oil reservoirs are now in their tertiary recovery phase and producers need to exploit enhanced oil recovery (EOR) techniques [10] to maintain production. By reinjecting $\mathrm{CO}_{2}$ and saline water into the reservoir, the loss of reservoir pressure is minimized and therefore the subsidence is limited. However, the ground water extraction remains an issue in the Houston-Galveston area. The ground water has been withdrawn for the purpose of meeting the needs of municipal supply, industry, and irrigation. Heavy groundwater pumping depressurizes and dewaters the major aquifers (Chicot and Evangeline) in this area, which causes compaction of the clay sediment layers of the aquifers [11, 12]. A study conducted 
by the U.S. Geological Survey (USGS) reported that, from 1943 to 1977, the groundwater withdrawals in the HoustonGalveston area resulted in a decline of water levels of as much as $76 \mathrm{~m}$ in wells completed in the Chicot aquifer and as much as $91 \mathrm{~m}$ in wells completed in the Evangeline aquifer [4].

In order to prevent land subsidence, the Texas Legislature created the Harris-Galveston Subsidence District (HGSD) in 1975 , “...for the purpose of ending subsidence, which contributes to or precipitates flooding, inundation, or overflow of the district, including without limitation rising waters resulting from storms or hurricanes" [13]. HGSD was authorized to issue (or refuse) well permits, promote water conservation and education, and promote conversion from ground-water to surface-water supplies. The Texas Legislature created the Fort Bend Subsidence District (FBSD) in 1989 [14] and the Lone Star Groundwater Conservation District (LSGCD) in 2001 [15] to manage groundwater resources and minimize land subsidence occurring in the Fort Bend County and the Montgomery County, respectively. These three districts (HGSD, FBSD, and LSGCD) operate a campaign style GPS network, which includes over 70 GPS stations. These GPS stations are called Port-A-Measure (PAM) stations. The earliest PAM sites were installed in 1993 [16]. The Texas Department of Transportation and other local agencies operate over 20 continuously operating reference stations (CORS) in the Houston-Galveston area [17]. The USGS has been operating 13 borehole extensometers at 11 sites since 1973 for the purpose of observing compaction of aquifers in this area [18].

From measurements recorded by 13 extensometers and 72 GPS stations in the Houston-Galveston area, we derived the average subsidence rate $(\mathrm{mm} /$ year$)$ in this area from 2006 to 2012 (Figure 1). The locations of these observational sites are plotted in Figure 1. The red lines represent the locations of about 150 principle faults mapped by USGS in the Houston area using airborne LIDAR data collected after tropical storm Allison in 2001 [19]. The tan blobs represent the locations of salt domes [20]. All GPS stations used for this study have a history of three years or longer.

The subsidence in Galveston, downtown Houston, and the area along the Houston Ship Channel has almost stabilized $(<3 \mathrm{~mm} /$ year). Subsidence greater than $10 \mathrm{~mm} /$ year and up to $25 \mathrm{~mm} /$ year is still occurring in land areas north and west of Houston, which include Spring, Jersey Village, Addicks, Katy, and the Sugar Land area. These areas are located in Regulatory Area 3 of the HGSD's 1999 and 2013 regulation plans $[13,21]$ or Area A of the 2003 FBSD regulation plan [14]. There was no groundwater regulation in these areas until 2010.

There are three primary aquifers in the HoustonGalveston area. They are the Chicot, Evangeline, and Jasper aquifers, which all belong to the Gulf Coast aquifer. There is a confining layer (Burkeville) between the Evangeline and Jasper aquifers (Figure 2). The youngest and uppermost portion of the Chicot aquifer consists of Holocene and Pleistocene age sediments; the underlying Evangeline aquifer consists of Pliocene and Miocene age sediments [22, 23]. The Chicot and Evangeline aquifers are composed of laterally discontinuous deposits of gravel, sand, silt, and clay. The oldest and most deeply buried Jasper aquifer consists of

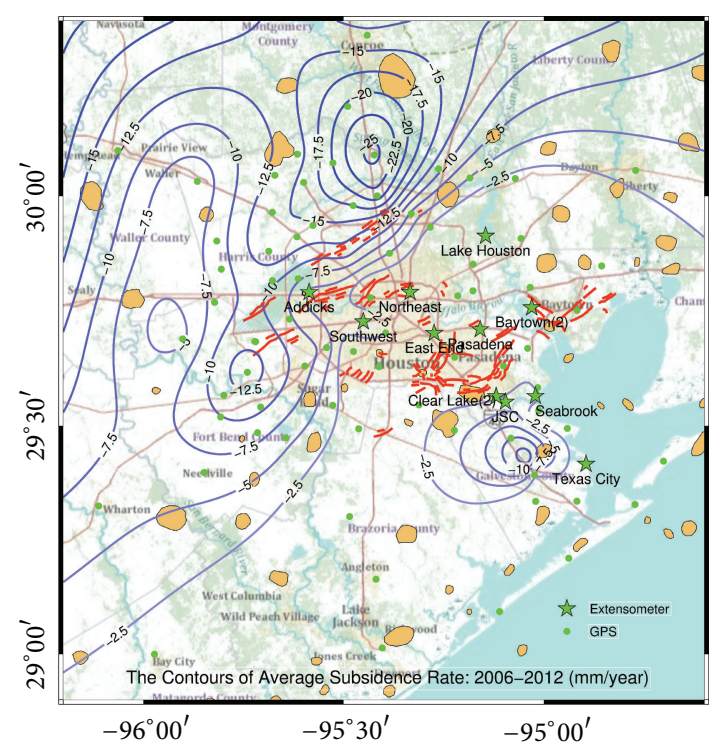

FIGURE 1: Map showing contours of the average subsidence rate ( $\mathrm{mm} /$ year) during the time span from 2006 to 2012. The contours are derived from subsidence observed from 72 GPS stations and 13 borehole extensometers. The red lines represent the locations of about 150 principle faults mapped by USGS in the Houston area using airborne LIDAR data collected after tropical storm Allison in 2001 [19]. The tan blobs represent the locations of salt domes [20].

Miocene age sediments. The two shallower aquifer units, the Chicot and Evangeline, have been described as being hydrologically connected [22]. This means that changes in the hydraulic properties of one aquifer will affect the properties of the other. However, the Jasper aquifer is not hydrologically connected to the Evangeline aquifer. This is because the Burkeville confining layer greatly restricts the vertical flow of groundwater from one aquifer to the other.

The borehole extensometers in the Houston-Galveston area were designed as "double pipe wells." These wells were drilled to preselected depths. Figure 2 illustrates a diagram depicting a cross-sectional perspective of the borehole extensometers at the Clear Lake and the Johnson Space Center (JSC) sites. The compaction of the interval between the land surface and the bottom of the inner pipe is continuously monitored by an analog recorder. Thus, extensometers are also called "compaction recorders." There is an opening screen (about $3 \mathrm{~m}$ in height) at the bottom of the outer casing of each borehole extensometer. This design allows each extensometer borehole to also function as a groundwater monitoring well, called a piezometer. The scientific theory and operation of borehole extensometers are explained by Poland and Yamamoto [24] and Gabrysch [25].

Figure 3 illustrates the close correlation between the compaction of aquifers and the change of groundwater level recorded at 13 extensometer sites operated by USGS (1973-2012). Red lines represent boreholes that were completed in the Chicot aquifer. Blue lines represent the boreholes that were completed in the Evangeline aquifer. Surface water from Lake Livingston became available to the Houston Ship 


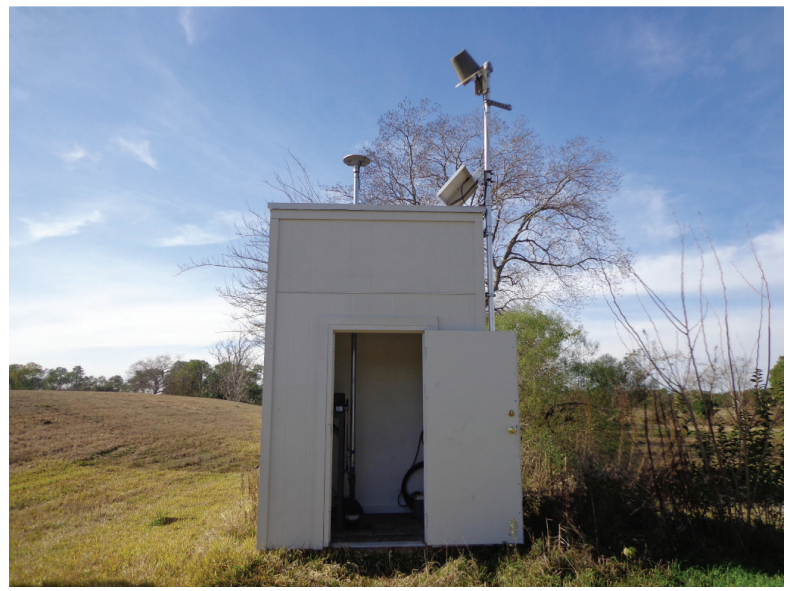

(a)

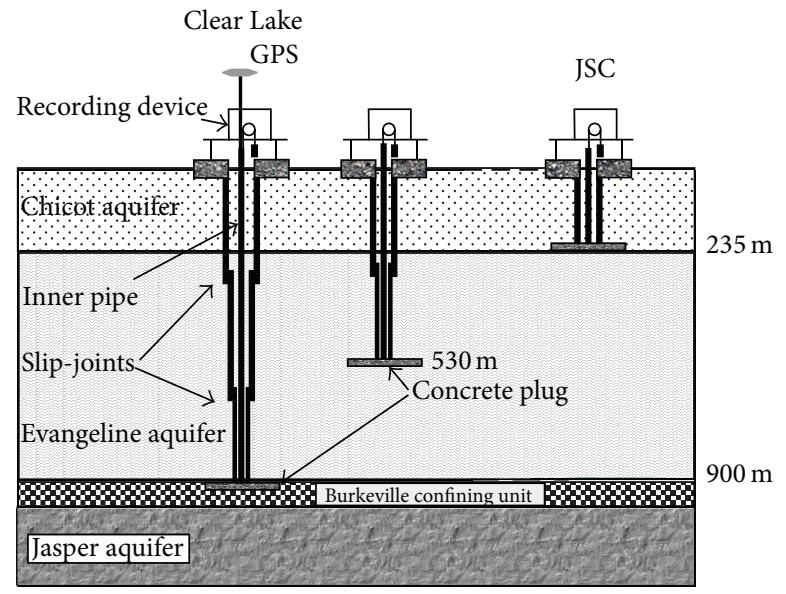

(b)

FIgUre 2: (a) A site photo showing the deep borehole extensometer and the collocated GPS station (TXEX) at the Clear Lake site. The GPS antenna is mounted on the extended inner pipe of the extensometer borehole, which is anchored in the strata $936 \mathrm{~m}$ below the ground surface. (b) A sketch depicting the local aquifers and borehole extensometers $(-936$ and $-530 \mathrm{~m})$ at Clear Lake and a nearby shallow extensometer $(-235 \mathrm{~m})$ at Johnson Space Center (JSC). The horizontal distance between the two extensometers at the Clear Lake site is $100 \mathrm{~m}$. The horizontal distance between the Clear Lake and JSC sites is $2.5 \mathrm{~km}$.

Channel area and the coastal area of Galveston in late 1976 [4]. This water was used to augment existing groundwater withdrawals. After 1976, groundwater withdrawals decreased significantly in both Galveston County and southeastern Harris County. The groundwater levels at all extensometer sites, except at Addicks, have been rising during the past four decades. As a result, the rates of aquifer compaction at the eastern and southeastern sites have been decreasing since 1990, about 14 years after starting to reduce groundwater withdrawals, as indicated by the shaded area in Figure 3(a). At the Texas City and Pasadena City sites the land surface has even rebounded slightly since 1990 . The groundwater level of the Evangeline aquifer at the Addicks site had been continuously decreasing $(2.5 \mathrm{~m} /$ year $)$ until 2001. As a result, the compaction at the Addicks site occurred continuously from 1973 to 2012. However, the compaction rate has decreased since 2001. The groundwater level is currently rising at the Addicks site at an average rate of $3 \mathrm{~m} /$ year. The recent
(2001-2012) subsidence rate at the Addicks site has declined to less than $1 \mathrm{~cm} /$ year from previous $4 \mathrm{~cm} /$ year (1974-2000) (Figure 4(a)). Compaction at this site will continuously occur as long as the groundwater head remains below the preconsolidation level (a critical value below which inelastic compaction of the fine-grained deposits occurs) within the aquifer systems in this area. The aquifer systems in this area include both clay and silt layers.

Figures 1 and 3 indicate that the groundwater regulations enforced by the subsidence districts have largely succeeded in their primary objective of limiting subsidence in the Houston-Galveston area. Long-term groundwater monitoring conducted by the USGS has indicated that the overall groundwater levels in both the Chicot and Evangeline aquifers have been increasing during the past two decades [18]. The districts' ability to limit subsidence raises a question: will the subsidence in the Houston-Galveston area eventually stop if the groundwater level reaches or exceeds the 
preconsolidation level in this area? This is an important question to consider for the long-term management of land and groundwater resources in the Houston-Galveston area. The same question has been asked in New Orleans. Researchers have found that there is deep-seated (or tectoniccontrolled) subsidence caused by deep-rooted faulting in the New Orleans area in addition to shallow subsidence associated with aquifer compaction [26-28]. Consequently, the subsidence in the New Orleans area is not likely to cease in the near future. This will be a great challenge to long-term coastal land management. The goal of this study is to explore if deep-seated subsidence is occurring in the Houston-Galveston area.

\section{Observations from Colocated GPS and Extensometers}

In 1993, the HGSD installed GPS antennas on the extended inner pipes of three borehole extensometers for the purpose of providing stable reference stations in the HoustonGalveston area. The three extensometers are located at Addicks, Lake Houston, and Northeast (Figure 1). There are two closely spaced $(100 \mathrm{~m})$ borehole extensometers at Clear Lake. In 2010, a GPS antenna was installed on the extended inner pipe of the deeper borehole extensometer at the Clear Lake site (Figure 2). The four GPS units located at Addicks, Lake Houston, Northeast, and Clear Lake are named ADKS, LKHU, NETP, and TXEX, respectively. The bottom of the inner pipe of each extensometer borehole was firmly anchored to the stratum at the bottom of the borehole. The depth of the boreholes at Addicks (ADKS), Lake Houston (LKHU), Northeast (NETP), and Clear Lake (TXEX) sites are 549, 591, 661, and $936 \mathrm{~m}$ below the land surface, respectively. The Addicks borehole was completed at the top of the Burkeville confining layer [4]. According to the sediment profile of the Houston-Galveston area provided by USGS [23], the extensometer boreholes at the Lake Houston and Northeast sites also reach the bottom of the Evangeline aquifer. In order to exclude the effect of superficial soil deformation associated with moisture, temperature, and biological changes, the concrete platform on the land surface around the borehole was built on piers bored six meters below the land surface $[16,29]$. As a result of this design, the extensometer measures aquifer compaction between the bottom of the borehole and six meters below the land surface. The GPS antenna reference point (ARP) measures the displacement as it translates to the anchored point at the end of the borehole inner pipe. Thus, the GPS antenna is able to measure the vertical displacement below the bottom of the borehole, which is called deep-seated subsidence in this paper. If such deep-seated subsidence does occur, it could be a combined result of the compaction of the underlying aquifer (Jasper), the consolidation of sediments below the Jasper aquifer, and possibly vertical displacement associated with tectonic movements. The GPS daily measurements are obtained by using the GIPSY/OASIS (V6.2) software package developed at the Jet Propulsion Laboratory. It uses precise point positioning (PPP) with single receiver phase ambiguity resolutions [30, 31]. According to our previous investigations, the daily PPP solutions would achieve $2-4 \mathrm{~mm}$ horizontal accuracy and $6-8 \mathrm{~mm}$ vertical accuracy in the Houston area $[17,32]$. The displacement time series of the vertical component represents the positional changes of the GPS antenna relative to the center of mass of the Earth.

Figure 4 illustrates the compaction (1975, 1980-2012) recorded by the extensometers and the deep-seated subsidence (1993-2013) recorded by the GPS antennas at the Addicks, Lake Houston, and Northeast sites. The extensometer-recorded compaction times series indicates that there has been $40 \mathrm{~cm}$ compaction of the shallow aquifers at the Addicks site and minor compaction $(<5 \mathrm{~cm})$ at the Lake Houston and Northeast sites since 1993. However, the GPS displacement time series indicates that there has been no considerable vertical displacement (subsidence) below the Evangeline aquifers at all three sites since 1993. Hence, the compaction recorded by extensometers at Addicks, Lake Houston, and Northeast sites accounts for the total subsidence at each site.

\section{Observations from Closely Spaced Extensometers}

With the closely spaced extensometers completed at different depths, we are able to estimate the variation of compaction rate in depth. Figure 5(a) illustrates the longterm (1975-2012) aquifer compaction recorded by two very closely spaced $(100 \mathrm{~m})$ extensometers at Baytown, which were completed at different depths $(-131$ and $-450 \mathrm{~m})$. According to the combined hydrogeological information published by USGS [22, 33], the depths of the bottom of the Chicot and Evangeline aquifers in this area are about 250 and $800 \mathrm{~m}$, respectively. Accordingly, the shallow borehole at the Baytown site was ended in the middle of the Chicot aquifer and the deep borehole was ended within the top one-third of the Evangeline aquifer. The compaction time series indicates that there was rapid compaction during the first 10 years of the monitoring period (1973 to 1983). The compaction accumulated within the Chicot aquifer $(-6 \mathrm{~m}$ to $-131 \mathrm{~m}, 15 \mathrm{~mm} /$ year) accounts for $50 \%$ of the total compaction ( $-6 \mathrm{~m}$ to $-450 \mathrm{~m}, 30 \mathrm{~mm} /$ year) during this time period. The total compaction includes the compaction within the whole Chicot aquifer and one-third of the Evangeline aquifer. Since there is no GPS antenna installed at the top of the inner pipe of the deep borehole, it is difficult to determine if the compaction recorded by the deep extensometer represents the total subsidence at this site. The compaction at the Baytown site was insignificant $(1.5-2 \mathrm{~mm} /$ year) at both shallow and deep borehole sites during the period from 1984 to 2009. However, it appears that rapid aquifer compaction has been occurring since 2010. The rapid compaction rates recorded by the shallow and deep extensometers are $50 \mathrm{~mm} /$ year and $20 \mathrm{~mm} /$ year, respectively. The two extensometer boreholes are only $100 \mathrm{~m}$ apart and the site-specific deformation within the top six meters has been excluded from extensometer recording. Thus, it is expected that the compaction recorded by the shallow extensometer should be no larger than the 


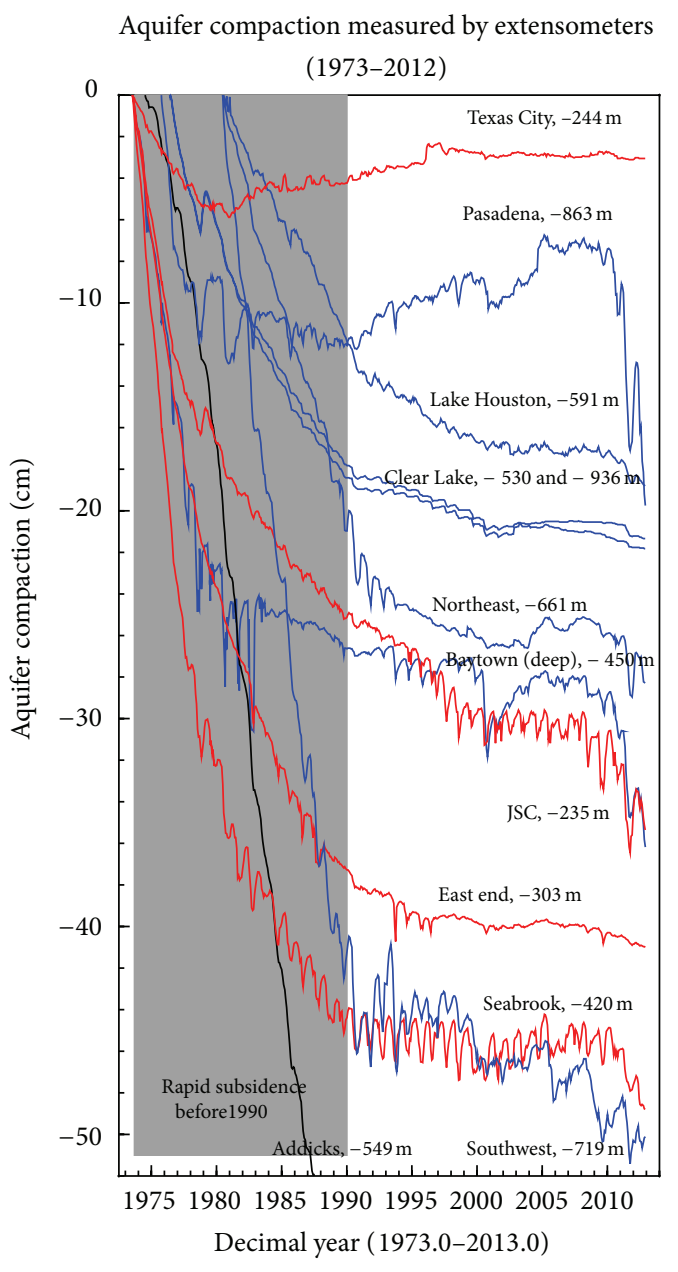

(a)

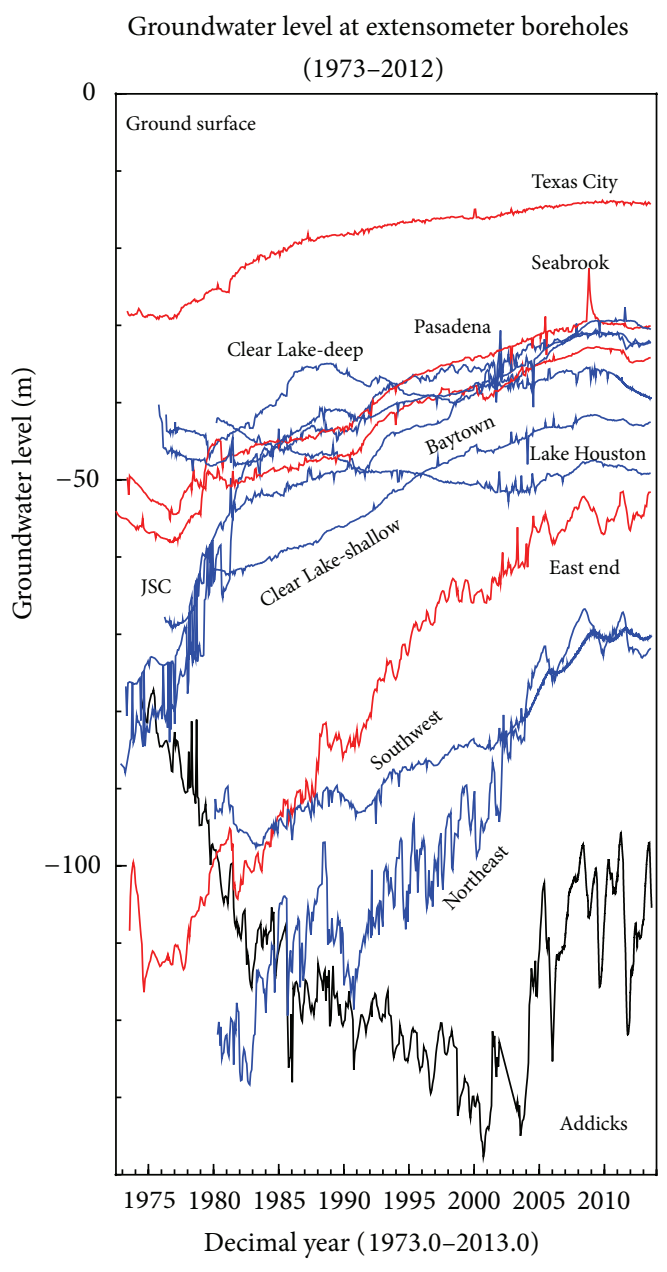

(b)

FIGURE 3: Plots depicting the history of aquifer compaction (a) and the level of groundwater head (b) observed at 13 extensometer sites in the Houston-Galveston area. The depth of each borehole is marked in the left figure. Red lines represent boreholes that were completed within the Chicot aquifer. Blue lines represent boreholes that were completed within the Evangeline aquifer.

compaction recorded by the deep extensometer. The anomaly of compaction curves at the Baytown site since 2010 implies that one or both extensometers have not been working properly since 2010.

Figure 5(b) illustrates the compaction time series recorded by two closely spaced extensometers at Clear Lake and one extensometer at Johnson Space Center. A vertical profile about the depths of the three borehole extensometers and the local aquifers is illustrated in Figure 2. The two borehole extensometers at Clear Lake were completed in the Evangeline aquifer at $530 \mathrm{~m}$ and $936 \mathrm{~m}$ below the land surface, respectively. The horizontal distance between the two extensometers is about $100 \mathrm{~m}$. The extensometer borehole at the Johnson Space Center (JSC) was completed $235 \mathrm{~m}$ below the land surface, which reached the bottom of the Chicot aquifer. The deeper borehole at Clear Lake was completed in the Burkeville confining layer $(-900 \mathrm{~m})$ [25]. The two extensometers $(-530 \mathrm{~m}$ and $-936 \mathrm{~m})$ at the Clear Lake site consistently recorded the same amount of compaction from 1976 to 2012. This indicates that there was no aquifer compaction between $530 \mathrm{~m}$ and $936 \mathrm{~m}$. In other words, the compaction at the Clear Lake site occurred within sediments shallower than $530 \mathrm{~m}$ below the land surface, which includes the whole Chicot aquifer and the top part of the Evangeline aquifer. The JSC extensometer is about $2.5 \mathrm{~km}$ southeast of the Clear Lake site. The cumulative compaction recorded at the JSC extensometer site reached the compaction recorded at the Clear Lake sites by the end of 2011. The observations at the Baytown, Clear Lake, and JSC sites suggest that most of the compaction was occurring in the Chicot aquifer and the top portion of the Evangeline aquifer.

\section{Tectonic Subsidence}

The Houston metropolitan area, and more broadly the Gulf Coast in general, has numerous gravitationally induced normal faults. Active faults in Houston were first recognized in as early as 1926 [7]. By 1973, about 52 faults had been recognized in the Houston area [34-36]. These faults had 


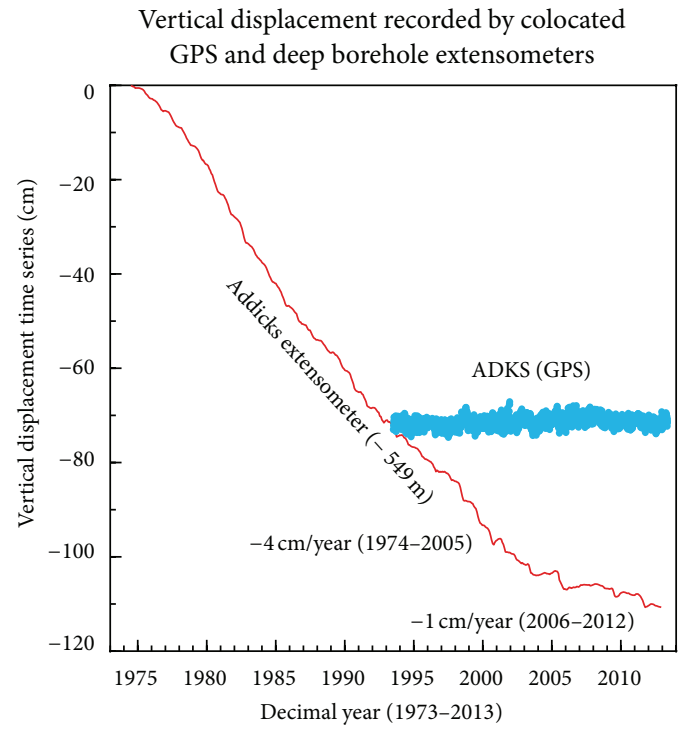

(a)

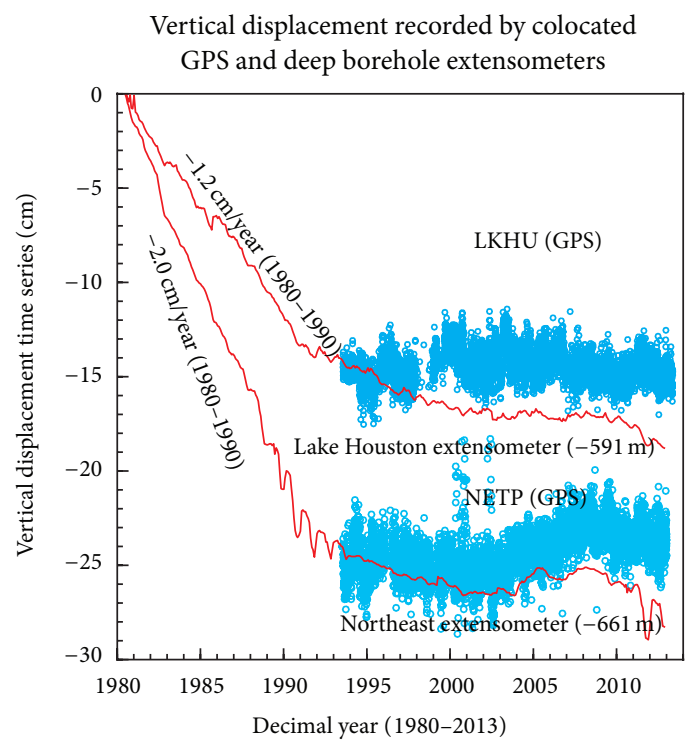

(b)

FIGURE 4: Comparisons of aquifer compaction recorded by extensometers and vertical displacements recorded by three GPS antennas mounted on the inner pipes of extensometer boreholes.

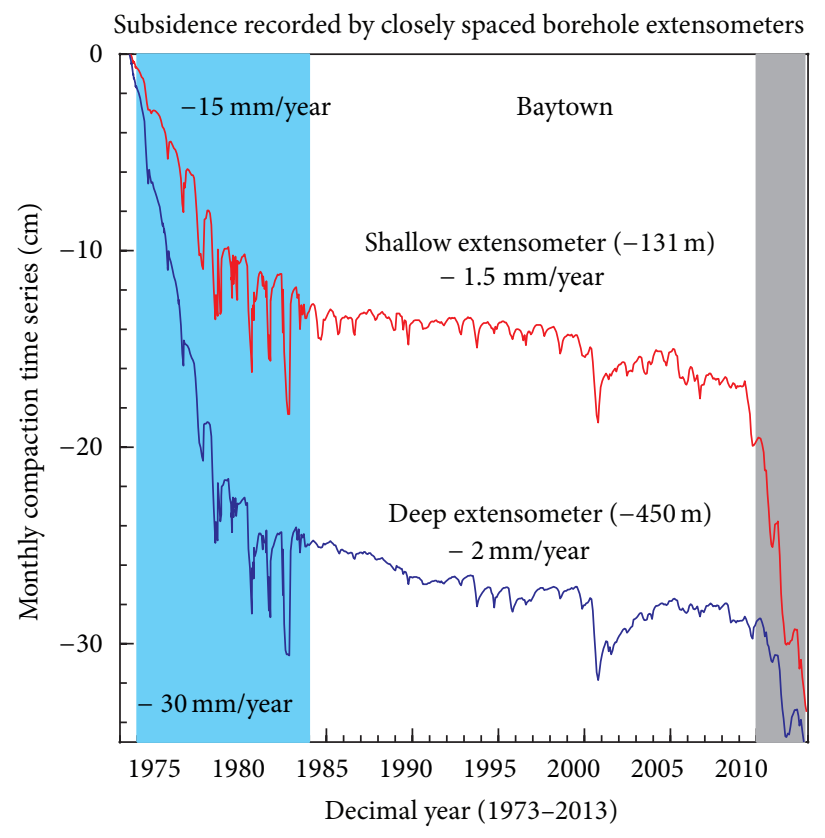

(a)

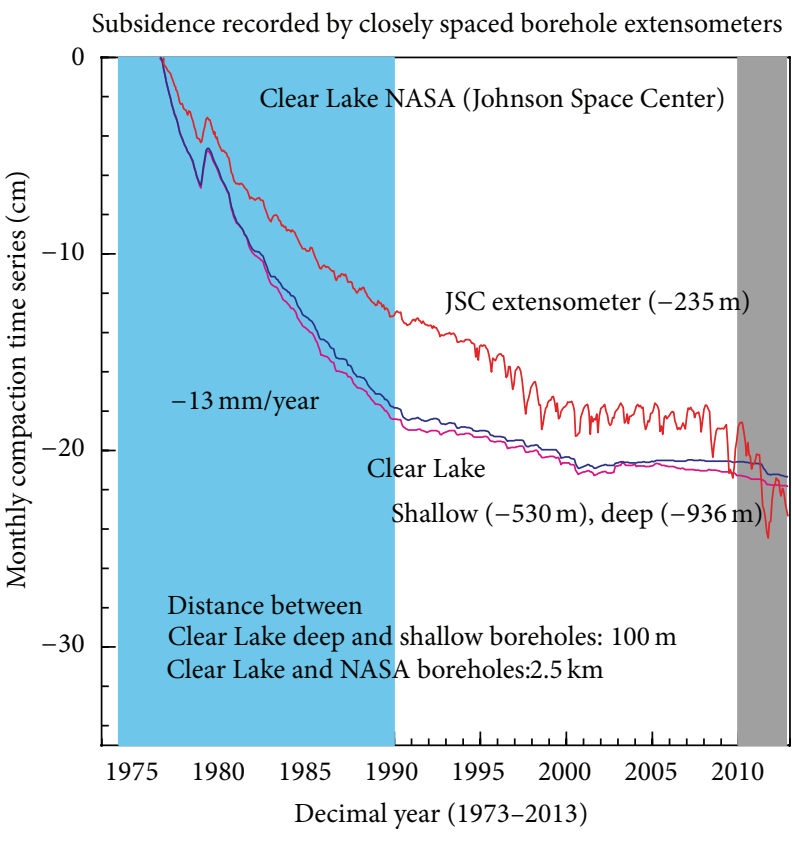

(b)

FIGURE 5: Aquifer compaction (1973-2013) recorded by five extensometers at Baytown, Clear Lake, and the Johnson Space Center (JSC).

an aggregate length of $220 \mathrm{~km}$ [37]. By 1979, the identified historically active faults had increased to over 150 in number and to more than $500 \mathrm{~km}$ in aggregate length [38]. Numerous subsurface faults have been documented beneath the Houston metropolitan area at depths from $800 \mathrm{~m}$ to $1250 \mathrm{~m}$ [38]. Some of these subsurface faults have affected shallower sediments and offset the present land surface. Unfortunately, active faults in the Houston area have not been thoroughly investigated for decades. This is because USGS budgets for mapping the faults in this area were eliminated in the late 1970s. As a result, most of the published research on active faulting dates from that time. Structural damage on or near the Earth's surface associated with ground deformation, such as damage to buildings, bridges, roads, and pipelines, has been frequently reported every year in the Houston area. The frequent superficial damage may imply that some faults are active. However, there are few quantitative studies about the depth of the fault creeping in the affected area. 
GPS position time series at four GPS sites colocated with deep borehole extensometers
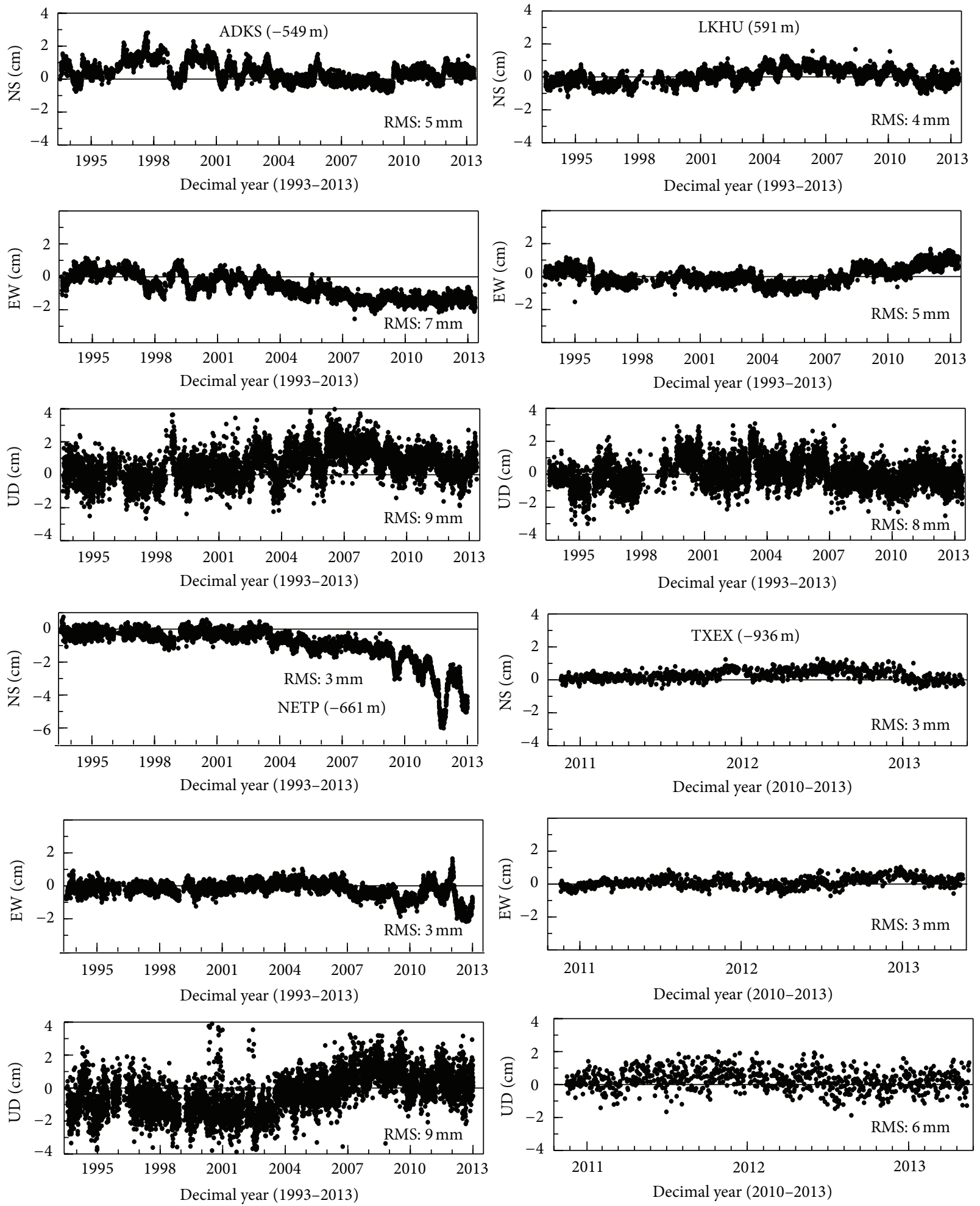

FIGURE 6: Three-component displacement time series recorded by four GPS antennas mounted on the inner pipes of borehole extensometers at Addicks (ADKS), Lake Houston (LKHU), Northeast (NETP), and Clear Lake (TXEX). 


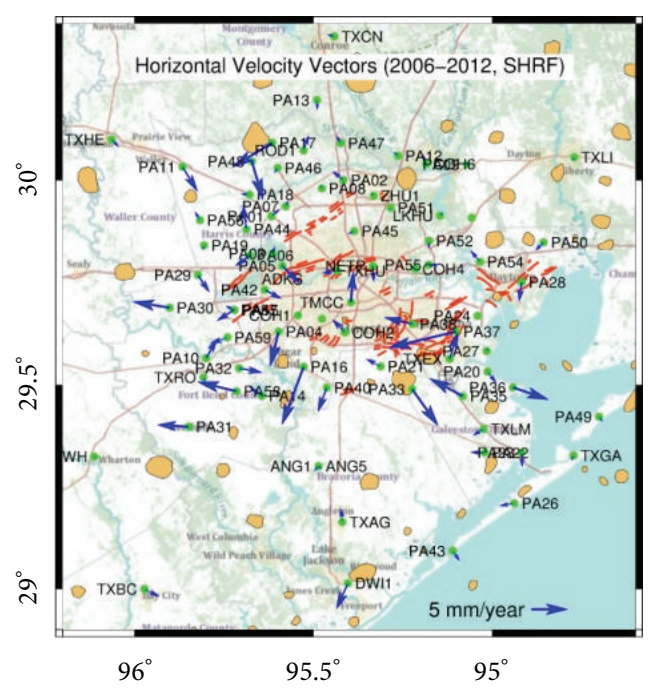

(a)

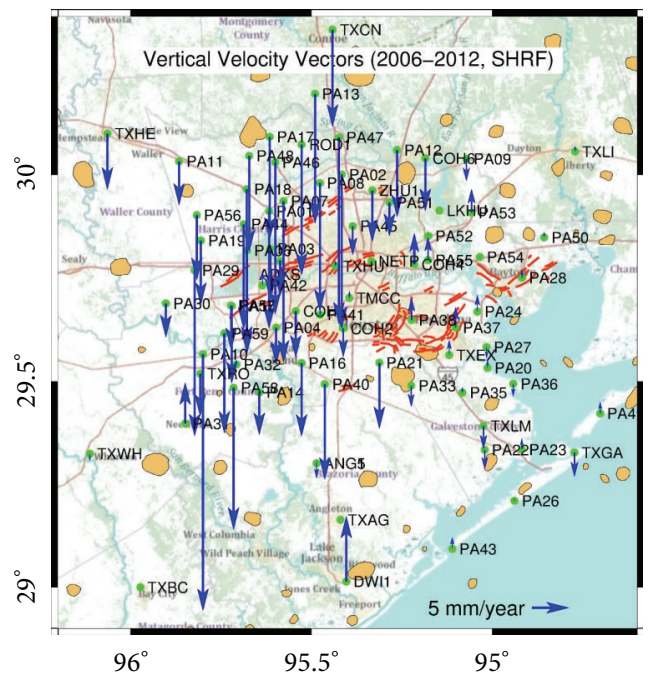

(b)

FIGURE 7: Recent horizontal and vertical ground deformation velocity vectors in the Houston-Galveston area derived from extensometer and GPS observations (2006-2012). The horizontal velocity vectors have been transformed to the stable Houston reference frame (SHRF). The red lines represent the locations of about 150 principle faults mapped by USGS in the Houston area using airborne LIDAR data collected after tropical storm Allison in 2001 [19]. The tan blobs represent the locations of salt domes [20].

Data from GPS sites in the Houston-Galveston area have been analyzed in this study to investigate the possible tectonic movement. Figure 6 illustrates long-term threecomponent positional time series derived from the GPS stations: ADKS, LKHU, NETP, and TXEX. The horizontal components, north-south (NS) and east-west (EW), have been transformed to the stable Houston reference frame (SHRF) from the original IGS08 reference frame [32]. The SHRF is defined by nine long-history continuously operating reference stations (CORS) outside the Houston area. The root-mean-squares (RMS) of the positional time series from all stations are less than one centimeter. We calculated the RMS value using data from 1993-2005 for stations ADKS,
LKHU, and NETP. The RMS value is also called repeatability or accuracy of GPS measurements in the geodesy community $[39,40]$. The three-component positional time series of these four GPS antennas indicate the antennas have been stable (total displacement $<2 \mathrm{~cm}$, except NETP-NS) in both vertical and horizontal directions during the past 20 years (1993-2012). This indicates that the strata at the bottom (about $-600 \mathrm{~m}$ ) of the boreholes did not experience any considerable subsidence.

Figure 7 illustrates the average horizontal and vertical ground displacement vectors derived from recent GPS observations (2006-2012) in the Houston-Galveston area. The horizontal ground movement vectors have been transformed 


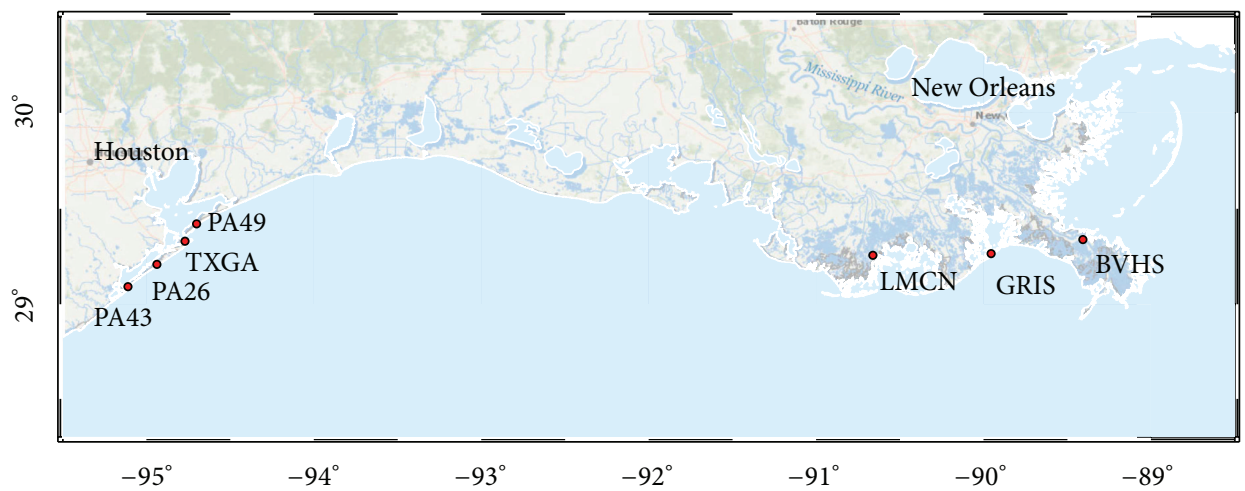

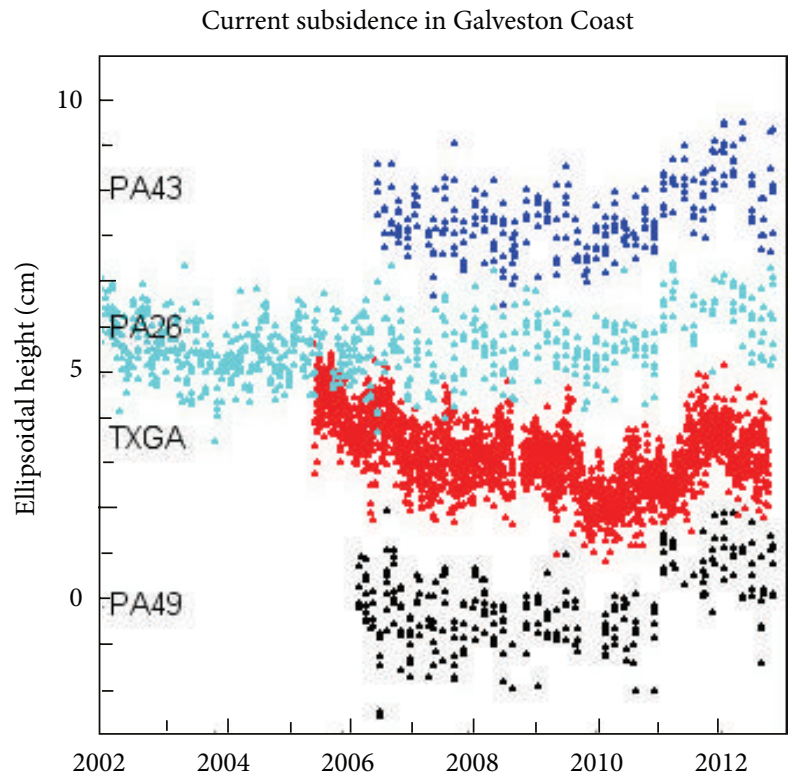

(a)

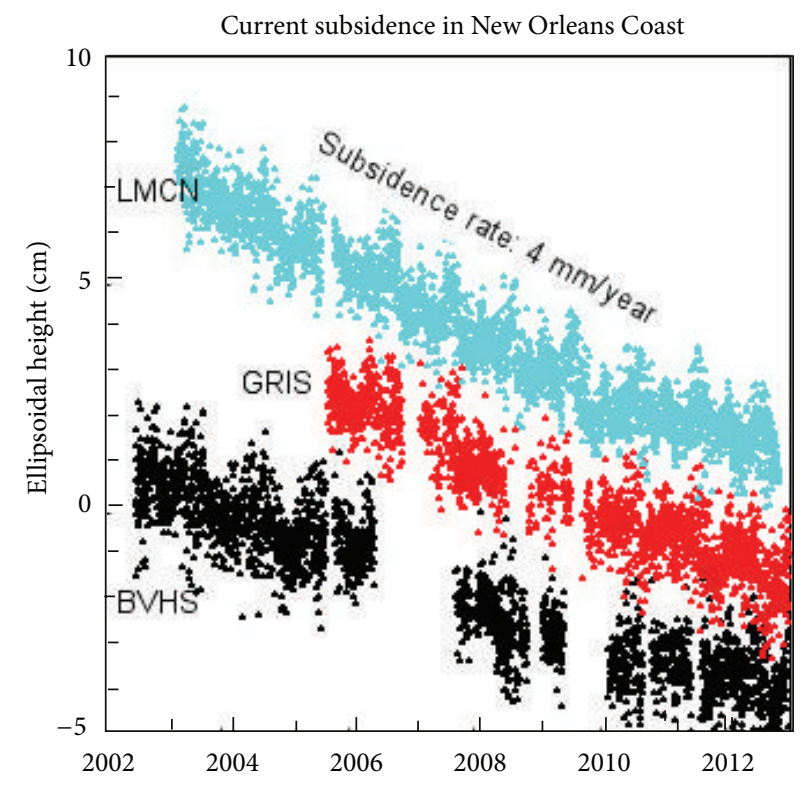

(b)

FIGURE 8: Comparisons of land subsidence currently occurring on the coast of Galveston, TX, (a) and on the coast of New Orleans, LA (b).

to the SHRF. The vertical ground displacement vectors are relative to the mass center of the Earth. The distribution of displacement vectors indicates that both horizontal and vertical ground displacements are site specific. The overall spatial correlations between the horizontal and vertical ground displacements are currently weak. There are no consistent horizontal local movements. A detailed review of positional time series from all GPS time series indicates that very few sites show steady horizontal movements. The overall horizontal movements are minor $(<5 \mathrm{~mm} /$ year $)$. The maximum subsidence rate is about $25 \mathrm{~mm} /$ year. It should be noted that potential superficial ground deformations within the top $6 \mathrm{~m}$ have been excluded from GPS observations since most GPS antennas are mounted on antenna poles that are anchored about $6 \mathrm{~m}$ below the land surface. Certain near fault ground displacements may have been missed from GPS observations because most GPS stations are at least a few kilometers away from the fault traces.

Dokka et al. $[27,28]$ proposed that deep-rooted faulting (tectonic) activities are dominating the subsidence in the New Orleans area. Several other studies [41-44] argued the "rapid" tectonic subsidence rates presented in Dokka’s works. However, many researchers agree that the New Orleans has been subsiding for a long period and the subsidence is not dominated by human activities. Understanding the occurrence of the tectonic subsidence is critical for designing an appropriate flood protection strategy in the New Orleans coastal area. Figure 8 illustrates vertical displacement time series (2002-2012) recorded at three permanent GPS stations along the New Orleans coastal area and four GPS stations along the Galveston coastal area. The three stations in New Orleans show steady subsidence with a rate of $4 \mathrm{~mm}$ /year. Dokka et al. [28] proposed that the steady subsidence is associated with a $7-10 \mathrm{~km}$ thick active allochthon that is detached from the stable North America plate. New Orleans lies on top of this active allochthon. The four stations on the Galveston coast do not show any considerable subsidence during the same time span (2002-2012). The GPS observations presented in Figure 8 indicate that the steady subsidence currently occurring in New Orleans is not occurring in Galveston. 


\section{Conclusion and Discussion}

This investigation indicates that the recent subsidence (1993-2012) in the Houston-Galveston area is dominated by the compaction of aquifers associated with groundwater withdrawals. The affected aquifers are limited to about $600 \mathrm{~m}$ below the land surface, which would include the Chicot and part or all of the Evangeline aquifer depending on the site where subsidence was monitored. The Chicot and Evangeline aquifers are the primary sources of the municipal groundwater supply in the Houston-Galveston area [3]. No measurable compaction was recorded in the Jasper aquifer or its underlying sediments. Deep-seated subsidence is not likely occurring in the Houston-Galveston area.

This study also indicates that the present subsidence rate could vary considerably even within a small area of a few square kilometers. This could be caused by differences in groundwater withdrawal near each site or by different clay-to-sand ratios in the subsurface sediments. Therefore, it is difficult to precisely extrapolate or infer a rate of subsidence for adjacent areas on the basis of the subsidence rate measured at a specific GPS or extensometer site. Hence, the contours of subsidence illustrated in Figure 1 should be interpreted with caution.

\section{Conflict of Interests}

The authors declare that there is no conflict of interests regarding the publication of this paper.

\section{Acknowledgments}

The authors thank USGS and HGSD for providing extensometer and GPS data to the public. The authors appreciate many thoughtful discussions with Mr. Mark G. Kasmarek at USGS. This study was supported by an NSF CAREER Award EAR-1229278 and an NSF MRI Award EAR-1242383.

\section{References}

[1] D. Galloway, D. Jones, and S. Ingebritsen, "Land subsidence in the United States," U.S. Geological Survey, U.S. Department of the Interior, Reston, Va, USA, 1999.

[2] R. Engelkemeir, S. D. Khan, and K. Burke, "Surface deformation in Houston, Texas using GPS," Tectonophysics, vol. 490, no. 1-2, pp. 47-54, 2010.

[3] G. Bawden, M. Johnson, and M. Kasmarek, Investigation of land subsidence in the Houston-Galveston region of Texas by using the Global Positioning System and Interferometric Synthetic Aperture, 1993-2000, U.S. Geological Survey, Reston, Va, USA, 2012.

[4] R. K. Gabrysch, Ground-Water Withdrawals and Land-Surface Subsidence in the Houston-Galveston Region, Texas, 1906-80, Texas Department of Water Resources, Austin, Tex, USA, 1984.

[5] M. C. Kasmarek, R. K. Gabrysch, and M. R. Johnson, Estimated Land-Surface Subsidence in Harris County, Texas, 1915-17 to 2001, U.S. Geological Survey, Reston, Va, USA, 1915.

[6] R. K. Gabrysch and C. W. Bonnet, Land-Surface Subsidence in the Houston-Galveston Region, Texas, Texas Water Development Board, Austin, Tex, USA, 1975.
[7] W. Pratt and D. Johnson, "Local subsidence of the goose creek oil field," The Journal of Geology, vol. 34, pp. 577-590, 1926.

[8] T. L. Holzer and R. L. Bluntzer, "Land subsidence near oil and gas fields, Houston, Texas.," Ground Water, vol. 22, no. 4, pp. $450-459,1984$.

[9] C. Cleveland, "A brief history of offshore oil drilling," 2013, http://www.eoearth.org/view/article/160618/.

[10] A. T. F. S. Gaspar Ravagnani, E. L. Ligero, and S. B. Suslick, " $\mathrm{CO}_{2}$ sequestration through enhanced oil recovery in a mature oil field," Journal of Petroleum Science and Engineering, vol. 65, no. 3-4, pp. 129-138, 2009.

[11] M. C. Kasmarek, M. R. Johnson, and J. K. Ramage, WaterLevel Altitudes 2010 and Water-Level Changes in the Chicot, Evangeline, and Jasper Aquifers and Compaction 1973-2009 in the Chicot and Evangeline Aquifers, Houston-Galveston Region, Texas, U.S. Geological Survey, Reston, Va, USA, 2010.

[12] M. R. Johnson, J. K. Ramage, and M. C. Kasmarek, WaterLevel Altitudes 2011 and Water-Level Changes in the Chicot, Evangeline, and Jasper Aquifers and Compaction 1973-2010 in the Chicot and Evangeline Aquifers, Houston-Galveston Region, Texas, U.S. Geological Survey, Reston, Va, USA, 2011.

[13] Harris-Galveston Subsidence District, Harris-Galveston Subsidence District Regulatory Plan, Adopted April 14, 1999, Amended September 12, 2001 and June 9, 2010, HarrisGalveston Subsidence District, Friendswood, Tex, USA, 1999.

[14] Fort Bend Subsidence District, Fort Bend Subsidence District 2003 Regulation Plan, Fort Bend Subsidence District, Richmond, Tex, USA, 2003.

[15] Lone Star Groundwater Conservation District, Long Start Groundwater Conservation District Management Plan, Long Start Groundwater Conservation District, Conroe, Tex, USA, 2008.

[16] D. B. Zilkoski, L. W. Hall, G. J. Mitchell et al., "The HarrisGalveston Coastal Subsidence District/National Geodetic Survey automated global positioning system subsidence monitoring Project," in Proceedings of the U.S. Geological Survey Subsidence Interest Group Conference, pp. 13-28, U.S. Geological Survey, Galveston, Tex, USA, 2003.

[17] G. Wang and T. Soler, "Using opus for measuring vertical displacements in Houston, Texas," Journal of Surveying Engineering, vol. 139, no. 3, pp. 126-134, 2013.

[18] M. C. Kasmarek, M. R. Johnson, and J. K. Ramage, WaterLevel Altitudes 2013 and Water-Level Changes in the Chicot, Evangeline, and Jasper Aquifers and Compaction 1973-2012 in the Chicot and Evangeline Aquifers, Houston-Galveston Region, Texas, U.S. Geological Survey, Reston, Va, USA, 2013.

[19] S. Shah and J. Lanning-Rush, Principal Faults in the Houston, Texas, Metropolitan Area, U.S. Geological Survey, Reston, Va, USA, 2005.

[20] American Association of Petroleum Geologists, Salt Tectonism of the U.S. Gulf Coast Basin, Tulsa, Okla, USA, 2011.

[21] Harris-Galveston Subsidence District, Harris-Galveston Subsidence District Regulatory Plan 2013, Harris-Galveston Subsidence District, Friendswood, Tex, USA, 2013.

[22] E. T. Baker, Stratigraphic and Hydrogeologic Framework of Part of the Coastal Plain of Texas, Texas Department of Water Resources, Austin, Tex, USA, 1979.

[23] E. T. Baker, Hydrology of the Jasper Aquifer in the Southeast Texas Coastal Plain, Texas Water Development Board, Austin, Tex, USA, 1986. 
[24] J. F. Poland and S. Yamamoto, "Field measurement of deformation," in Guidebook to Studies of Land Subsidence due to GroundWater Withdrawal, J. F. Poland, Ed., pp. 17-35, United Nations Educational Scientific and Cultural Organization, Paris, France, 1984.

[25] R. K. Gabrysch, "Subsidence in the Houston-Galveston region, Texas, USA," in Guideb. to Stud. L. Subsid. due to GroundWater Withdrawal, J. F. Poland, Ed., pp. 253-262, United Nations Educational Scientific and Cultural Organization, Paris, France, 1984.

[26] R. K. Dokka, "Modern-day tectonic subsidence in coastal Louisiana," Geology, vol. 34, no. 4, pp. 281-284, 2006.

[27] R. K. Dokka, "The role of deep processes in late 20th century subsidence of New Orleans and coastal areas of southern Louisiana and Mississippi," Journal of Geophysical Research B: Solid Earth, vol. 116, no. 6, Article ID B06403, 2011.

[28] R. K. Dokka, G. F. Sella, and T. H. Dixon, “Tectonic control of subsidence and southward displacement of southeast Louisiana with respect to stable North America," Geophysical Research Letters, vol. 33, no. 23, Article ID L23308, 2006.

[29] G. Wang, J. Yu, T. J. Kearns, and J. Ortega, "Assessing the accuracy of long-term subsidence derived from borehole extensometer data using GPS observations: a case study in Houston, Texas," Journal of Surveying Engineering, 2014.

[30] J. F. Zumberge, M. B. Heflin, D. C. Jefferson, M. M. Watkins, and F. H. Webb, "Precise point positioning for the efficient and robust analysis of GPS data from large networks," Journal of Geophysical Research B: Solid Earth, vol. 102, no. 3, Article ID 96JB03860, pp. 5005-5017, 1997.

[31] W. Bertiger, S. D. Desai, B. Haines et al., "Single receiver phase ambiguity resolution with GPS data," Journal of Geodesy, vol. 84, no. 5, pp. 327-337, 2010.

[32] G. Wang, J. Yu, J. Ortega, G. Saenz, T. Burrough, and R. Neill, "A stable reference frame for the study of ground deformation in the Houston metropolitan area, Texas," Journal of Geodetic Science, vol. 3, pp. 13-27, 2013.

[33] M. C. Kasmarek, M. R. Johnson, and J. K. Ramage, Water-level altitudes 2012 and water-level changes in the Chicot, Evangeline, and Jasper aquifers and compaction 1973-2011 in the Chicot and Evangeline aquifers, Houston-Galveston region, Texas, U.S. Geological Survey, Reston, Va, USA, 2012.

[34] P. Weaver and M. M. Sheets, "Active faults, subsidence, and foundation problems in the Houston, Texas, area," in Geology of the Gulf Coast and Central Texas, and Guidebook of Excursions, E. H. Rainwater and R. P. Zingula, Eds., pp. 254-265, Houston Geological Society, Houston, Tex, USA, 1962.

[35] D. C. van Siclen, “The Houston fault problem," in Proceedings of the 3rd annual Convention, Texas Section, pp. 9-31, American Institute of Professional Geologists, Houston, Tex, USA, 1967.

[36] M. M. Sheets, "Active surface faulting in the Houston area, Texas," Houston Geological Society Bulletin, vol. 13, pp. 24-33, 1971.

[37] W. M. Reid, Active faults in Houston, Texas [Ph.D. thesis], University of Texas at Austin, 1973.

[38] E. R. Verbeek, K. W. Ratzlaff, and U. S. Clanton, Faults in Parts of North-Central and Western Houston Metropolitan Area, Texas, Texas, U.S. Geological Survey, Reston, Va, USA, 1979.

[39] G. Wang, "GPS landslide monitoring: single base vs. network solutions-a case study based on the Puerto Rico and Virgin Islands permanent GPS network," Journal of Geodetic Science, vol. 1, no. 3, pp. 191-203, 2011.
[40] G. Wang and T. Soler, "Opus for horizontal subcentimeteraccuracy landslide monitoring: case study in the Puerto Rico and Virgin Islands Region," Journal of Surveying Engineering, vol. 138, no. 3, pp. 143-153, 2012.

[41] K. T. Milliken, J. B. Anderson, and A. B. Rodriguez, "A new composite Holocene sea-level curve for the northern Gulf of Mexico," in Response of Upper Gulf Coast Estuaries to Holocene Climate Change and Sea-Level Rise, J. B. Anderson and A. B. Rodriguez, Eds., pp. 1-12, Geological Society of America Special Papers, Boulder, Colo, USA, 2008.

[42] T. E. Törnqvist, D. J. Wallace, J. E. A. Storms et al., "Mississippi Delta subsidence primarily caused by compaction of Holocene strata," Nature Geoscience, vol. 1, no. 3, pp. 173-176, 2008.

[43] A. S. Kolker, M. A. Allison, and S. Hameed, "An evaluation of subsidence rates and sea-level variability in the northern Gulf of Mexico," Geophysical Research Letters, vol. 38, no. 21, Article ID L21404, 2011.

[44] A. R. Simms, J. B. Anderson, R. DeWitt, K. Lambeck, and A. Purcell, "Quantifying rates of coastal subsidence since the last interglacial and the role of sediment loading," Global and Planetary Change, vol. 11, pp. 296-308, 2013. 

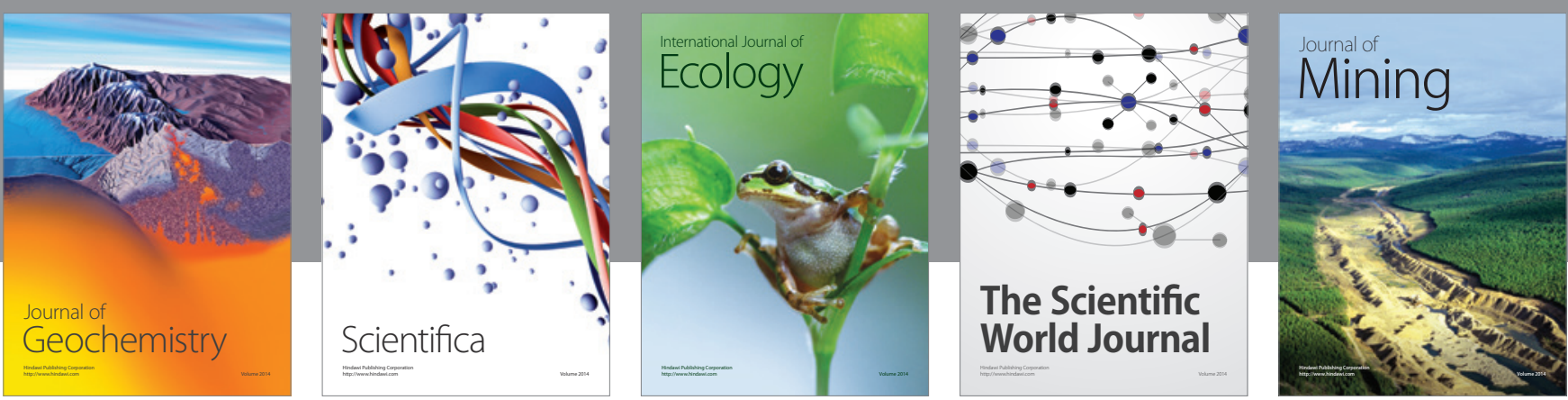

The Scientific World Journal
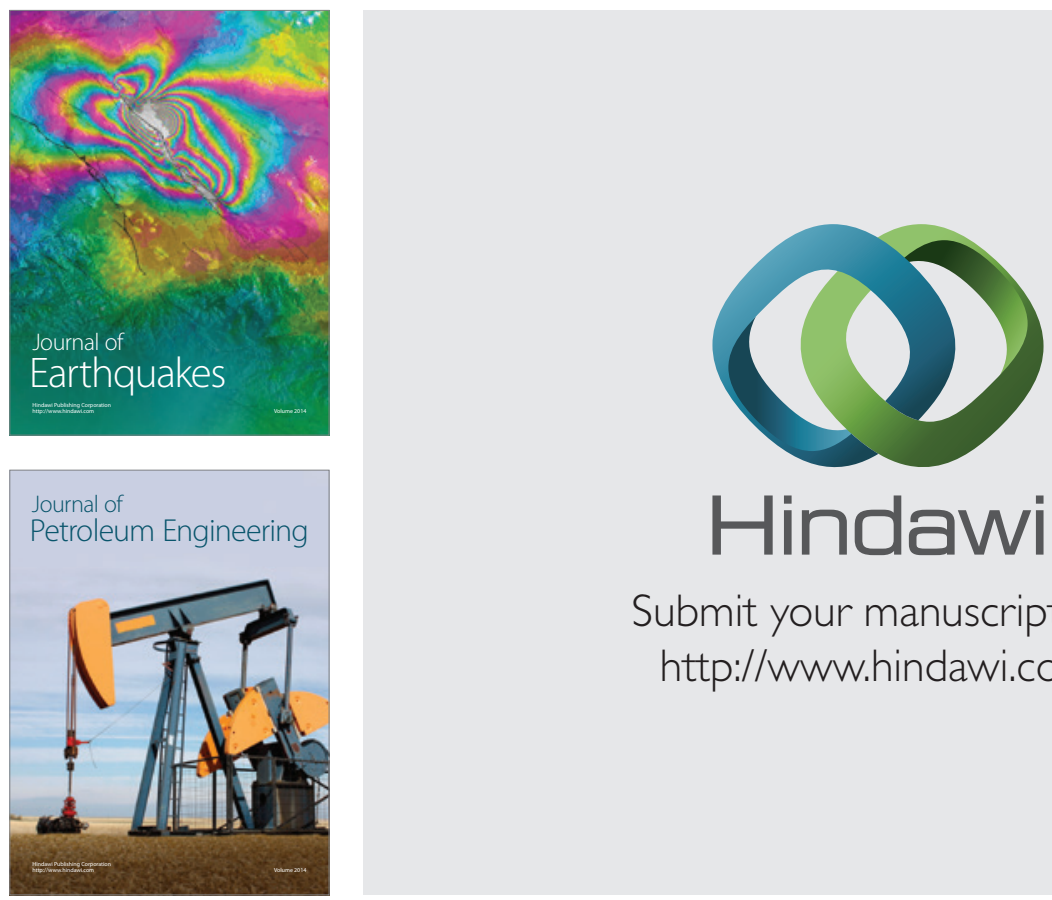

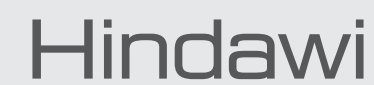

Submit your manuscripts at

http://www.hindawi.com
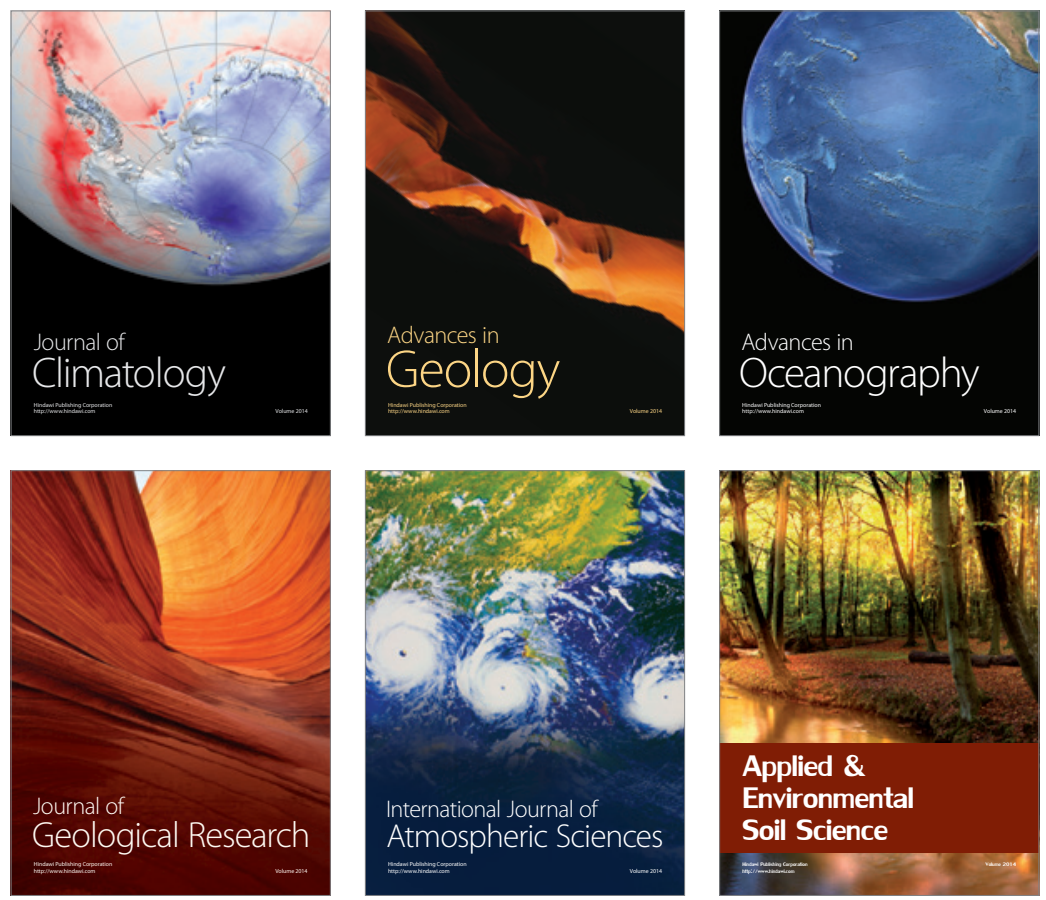
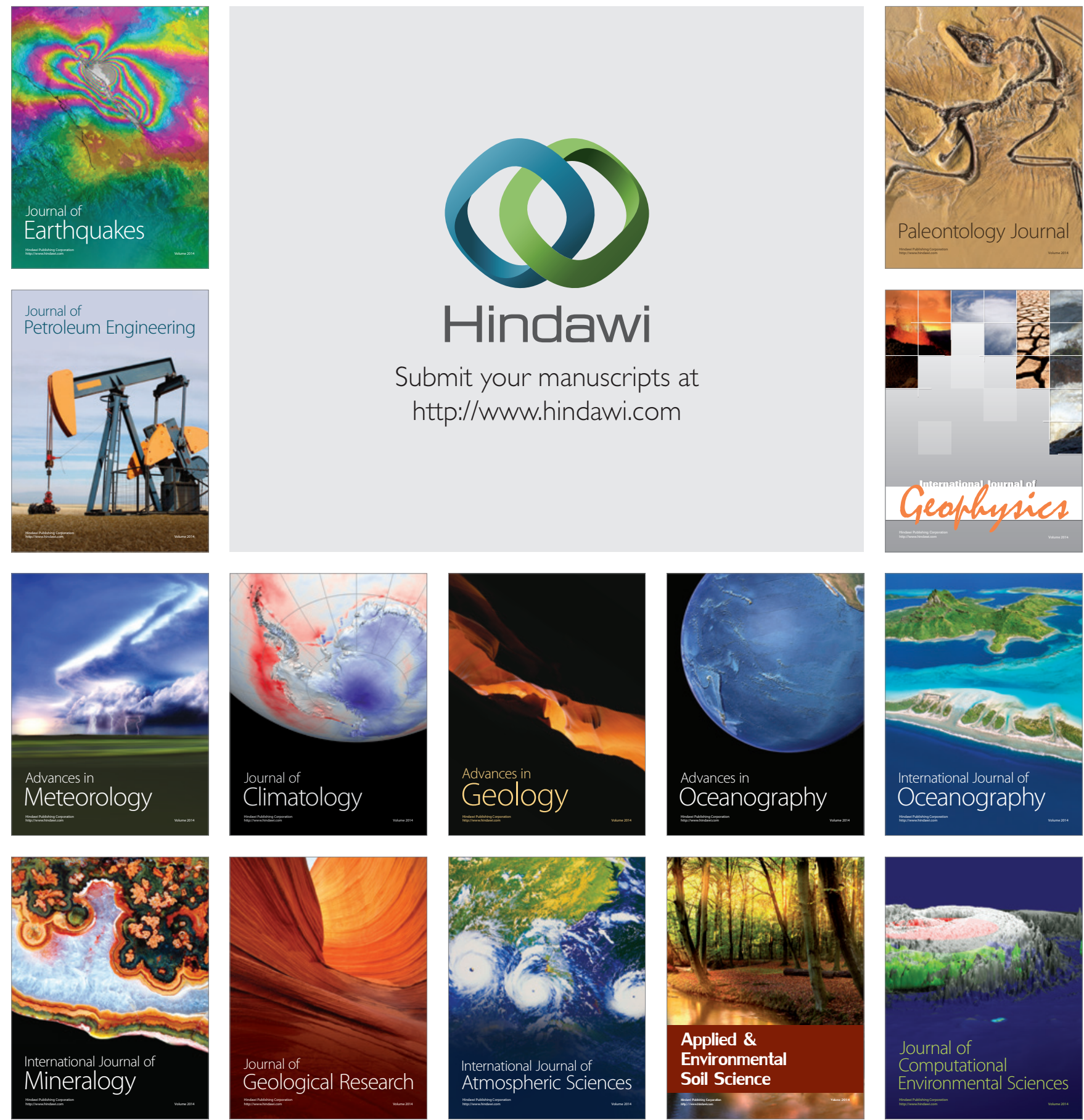